\title{
The Big Picture: Trends from the Academic Business Library Directors' Year in Review Reports 2018-2019
}

\author{
GREG FLEMING \\ University of Chicago, Chicago, IL \\ gdf@uchicago.edu \\ CAROL DOYLE \\ Northwestern University, Evanston, IL \\ c-doyle4@northwestern.edu
}

\begin{abstract}
This paper presents a summary of Year in Review reports of members of the Academic Business Library Directors (ABLD). Themes include new and ongoing initiatives in libraries, library collections, organizational change in libraries and member business schools and changes in library spaces.
\end{abstract}

Keywords academic business libraries, library trends, organizational changes, new initiatives, business schools, Academic Business Library Directors (ABLD)

\section{Year in Review}

The Academic Business Library Directors (ABLD) group meets annually in the spring. Part of the preparation for this meeting is the submission of year in review reports by individual members. These reports summarize new and ongoing initiatives, changes in organizations and physical spaces, and vendor and collection issues in the members' libraries. They also address issues, changes and challenges related to the members' business schools. The 2019 meeting took place April 16-19 in Boston and was hosted by Harvard Business School, featuring the theme "The Evolving Business Library." The ABLD meeting features a session where the themes from the members' reports are summarized. This article highlights some of the major trends and themes from that session, which were presented using the theme "Painting the Big Picture."

\section{Notable Trends Overall}

Many of the themes that emerged from members' reports echoed themes from past years, including shrinking staff, repurposed spaces, and increased demands on collection budgets. Data continues to be at the top of the list of student and faculty requests. Print collections are shrinking as space is repurposed. Support for entrepreneurship is also an important area of focus for many libraries. Staff changes in libraries and business schools are contributing to feelings of constant change for many members.

\section{New and Ongoing Initiatives}

Member libraries continued their evolution by seeking new ways to reach their own students as well as seeking opportunities with campus partnerships and community outreach. Interdisciplinary programs are increasingly drawing on business resources, putting new demands on limited resources.

Course material affordability has been an issue in higher education for many years. Textbooks have received most of the attention, but course packs have also had an impact due to the cost of copyright 
Ticker: The Academic Business Librarianship Review, 4:2 (2020)

http://doi.org/10.3998/ticker.16481003.0004.202

(c)2020 Greg Fleming and Carol Doyle

clearance. Several members are involved in initiatives to help address these costs. Indiana University librarians worked with business faculty to create an affordable textbook for the business presentations course. Michigan State purchased required textbooks for all business courses and placed them on reserve for spring quarter. "This was a giant step away from our traditional policy of not buying textbooks at all, with rare exception" (ABLD, 2019, p. 48). The library at Carnegie Mellon is establishing a textbook donation library, where graduating MBA students can donate their books for future students' use (ABLD, 2019 , p. 14). The University of California Berkeley took over the process of building course readers, in an effort to leverage materials that the library had already licensed (ABLD, 2019, p. 76). Conversely, the University of Washington Library is emphasizing open educational materials (OER), which could be detrimental to the business library acquiring data and other materials requested by faculty for their research needs (ABLD, 2019, p. 87).

Support for entrepreneurial programs continues to grow. Carnegie Mellon increased its outreach and collaboration with the Swartz Center for Entrepreneurship and is considering adding consultation hours in the Swartz Center (ABLD, 2019, p. 14). Indiana embarked on initiatives to add instructional and research support for the business school and other campus partners. They are also working with the university's Center for Rural Engagement and the public library to create programming for entrepreneurs outside of the university community (ABLD, 2019, p. 37). Maryland participated in "UMD StartUp@ the University Libraries," the inaugural event co-sponsored by the university's Office of Technology Commercialization. They hope to make the library one of the campus hubs for student startups by offering resources for their support (ABLD, 2019, p. 41). Purdue noted that they are facing a growing demand for support for entrepreneurs from across campus (ABLD, 2019, p. 71) and SMU has had greater involvement with entrepreneurship and innovation programs across campus (ABLD, 2019, p. 72). Michigan State hired an entrepreneurship librarian (ABLD, 2019, p. 50) and Penn State was in the process of recruiting one (ABLD, 2019, p. 63).

Many libraries expanded programs to work with campus partners in geographical information systems (GIS). Carnegie Mellon worked to provide sessions to the Tepper School on visualization (ABLD, 2019, p. 14), Dartmouth is in the planning stages to launch a series of workshops (ABLD, 2019, p. 21) and Northwestern's GIS analysts have been working with the Kellogg School on real estate research (ABLD, 2019, p. 56). The University of British Columbia (UBC) Library will lead a project to build the Federated Geospatial Data Discovery for Canada (ABLD, 2019, p. 10).

Financial literacy has been used as a way to increase library visibility on campus and in the surrounding community. The University of Maryland continues to offer Money Talks, held in cooperation with the Society for Financial Awareness. Topics include retirement planning, budgeting and other areas of money management. The talks are open to the broad Maryland community and the general public (ABLD, 2019, p. 40). Michigan State is working with campus development on a proposal to fund a series of financial literacy events (ABLD, 2019, p. 48). Penn State has organized a series of programs under the title "The Informed Consumer" with the goal of helping students develop life skills beyond finance (ABLD, 2019, p. 63).

Web conferencing services were implemented with great success by Harvard, Southern Methodist and Penn. Harvard provided training through videoconferencing for research staff at their global locations, including sessions on research skills and using Zotero for citation management. They also did a pilot session for their London Alumni Club and plan to expand that program (ABLD, 2019, p. 31). SMU used the launch of a new online MBA program to expand their presence in their course management system, 
Ticker: The Academic Business Librarianship Review, 4:2 (2020)

http://doi.org/10.3998/ticker.16481003.0004.202

(C)2020 Greg Fleming and Carol Doyle

embedding chat and appointment scheduling for videoconferencing research consultations (ABLD, 2019, p. 72). Penn implemented appointment scheduling as well and found it helped students better understand their options for video consultations (ABLD, 2019, p. 67).

The HEC Montreal library is changing to focus on support for research data and associated expertise. The Computing and Data Mining Laboratory and the Mathematics and Statistics Help Center were integrated with the library and will offer services for data analysis. This included staff with significant statistical expertise, who will consult with graduate students and faculty (ABLD, 2019, pp. 35-36).

Non-traditional services are another way libraries continue to evolve. Duke expanded services to better accommodate students with disabilities. This included a review of the web site to ensure it was fully accessible to screen readers and extended loan periods and scanning services for students who need accommodation (ABLD, 2019, p. 24). Two libraries reported stress relief programs during final exams. UCLA offered massages (ABLD, 2019, p. 79) while Vanderbilt had hot chocolate and baby goats (ABLD, 2019 , p. 81). UBC hosted a winter event highlighting campus libraries. It featured a train highlighting the transportation collection, displays of winter-themed collections and caroling and pictures with Santa (ABLD, 2019, p. 10). Michigan and Michigan State planned to compete in a charity food drive in the late spring, with bragging rights for the library that collected the most (ABLD, 2019, p. 47).

\section{Library Collections}

Change is constant in business library collections. Members reported 114 new or expanded database subscriptions and 58 cancellations or reductions in coverage. And as Dartmouth reflected, "new and wished-for resources continue to come along faster than the budget can keep up" (ABLD, 2019, p. 22). Duke is trying to move to multi-year deals as much as possible to help keep costs down (ABLD, 2019, p. 25). Boston University is reviewing and cancelling print titles to free up money for online resources (ABLD, 2019, p. 9).

The University of California was unable to come to an agreement with Elsevier and cancelled their journal package for the entire system. Access had not been cut off at the time of UC Berkeley's report, so they had not received complaints (ABLD, 2019, p. 77).

Faculty licensing data at Michigan State are now required to have the library review the license agreement before the purchase can be made. The library learned a great deal through this process, including that faculty had little experience with license negotiations and rarely requested changes to license terms (ABLD, 2019, p. 50).

Babson College noted the move of many vendors to single sign-on rather than network address for authentication (ABLD, 2019, p. 6), but Penn and Washington see potential conflicts with their universities' privacy policies (ABLD, 2019, pp. 69, 87). Vendors may be receiving more personal information than users realize. UBC has the additional complexity of navigating British Columbia privacy law and how it applies to private information stored on vendor servers in the United States (ABLD, 2019, p. 12).

Increased text and data mining requests were noted by Indiana University and the University of Toronto. Both also reported problems with vendors delivering data or not making it available at all (ABLD, 2019, pp. 39, 75). 
Ticker: The Academic Business Librarianship Review, 4:2 (2020)

http://doi.org/10.3998/ticker.16481003.0004.202

(C)2020 Greg Fleming and Carol Doyle

\section{Evolving Organizations}

Nine libraries reported changes in their organization or reporting lines. New deans or associate deans came on board at eight libraries.

Cornell restructured the administration of the three business libraries, moving the Hotel and Management libraries into a reporting structure with the Engineering library (ABLD, 2019, p. 19). Dartmouth created the position of Head of Research \& Data Services, which brought the Business and Engineering libraries under one director (ABLD, 2019, p. 21). Notre Dame created new interest groups for collections discussions and the business librarians were shifted away from working with STEM librarians to a broad group of social sciences, humanities and area studies librarians (ABLD, 2019, p. 58). Penn reorganized for the third time in three years and the business library is now part of the Branch Libraries group, reporting to the AUL for STEM and Business Libraries (ABLD, 2019, p. 67). SMU now reports to the university library with a dotted line to the business school, which was a result of the provost deciding to centralize all library services. The financial arrangements of the new reporting lines were still being negotiated (ABLD, 2019, p. 72).

The weakness of business librarian applicant pools was noted as it has been in previous reports. It has been challenging for Northwestern to attract a large enough pool (ABLD, 2019, p. 57). Emory has had a position open for over a year, but their pool has been limited and disappointing (ABLD, 2019, p. 27).

\section{Business School Changes}

This year, leadership changes had taken place or were underway at in the business schools at Babson College, Boston University, Cornell, HEC Montreal, Northwestern University, the University of California Berkeley, Notre Dame, Western University, Yale, and the University of Washington (ABLD, 2019 , pp. 7, 9, 20, 36, 57, 59, 86, 89, 93). The University of Alabama business school name was officially changed to the Culverhouse College of Business (ABLD, 2019, p. 3).

Business schools also continue to expand their course offerings and degrees. Eighteen members reported new degrees or programs. Data and analytics are still a focus of many new business school initiatives and degrees. Boston University introduced a master of business analytics degree and six new data analytics course (ABLD, 2019, p. 9). The University of Washington added a master of business analytics (ABLD, 2019, p. 86), while UCLA saw its first graduates of their master of business analytics (ABLD, 2019, p. 80). The University of Toronto began a master's in management analytics (ABLD, 2019, p. 75) and Penn State a master's in marketing analytics (ABLD, 2019, p. 64).

Online degrees and programs are also a major area of expansion for business schools. New degrees have been launched or are about to be launched at Indiana, Michigan, NYU, Penn State, SMU, and Wake Forest (ABLD, 2019, pp. 39, 46, 62, 64, 72, 84).

\section{Spaces}

Campus spaces continue to be an area of growth and reconfiguring. Sixteen institutions had changes or new buildings underway during 2018-2019. The demand for student study space has been an impetus for libraries to weed their collections and remove lesser used print journals and reference sources.

The University of Alabama College of Business is building a new facility near the library, which will result in the library getting new carpet and some new furniture. The library will also move most bound 
Ticker: The Academic Business Librarianship Review, 4:2 (2020)

http://doi.org/10.3998/ticker.16481003.0004.202

(C)2020 Greg Fleming and Carol Doyle

periodicals to storage (ABLD, 2019, p. 3). UCLA and Michigan State are also in the process of adding new business school buildings (ABLD, 2019, pp. 51, 79), while Carnegie Mellon opened the Teppan Quad as a new home for its business school (ABLD, 2019, p. 15). Building renovations at Yale caused an increased use of the library for study space (ABLD, 2019, p. 93). Librarians at Dartmouth are preparing to vacate the Feldberg Library for two years while a new building is constructed that will house the Magnusson Center for Entrepreneurship and other campus units (ABLD, 2019, p. 21).

Library renovations and reconfigurations took place or are underway at many members. Duke conducted a space study and removed collections and stacks to create more study space (ABLD, 2019, p. 24). The University of Toronto also removed collections and shelving, in this case to create more office space (ABLD, 2019, p. 74). The Kresge Library at the University of Michigan redid its space to accommodate thirteen staff members from the business school's new office of digital education (ABLD, 2019, pp. 44-45). NYU changed its guest access policies to reduce over-crowding in its study spaces (ABLD, 2019, p. 61). Penn State completed a new glass entrance to their business commons, which provides an attractive and inviting space for consultations (ABLD, 2019, p. 64). UC Berkeley has a proposal for renovation of their space, but funding is unclear at the time of their report (ABLD, 2019, pp. 76-77). Georgetown University is closing its science library, and all librarians are relocating to the main library (ABLD, 2019, p. 29). The science and humanities library at MIT closed in 2019 for a major renovation and will reopen in 2020 (ABLD, 2019, p. 53). Babson College deaccessioned almost half of its collection in preparation for a renovation which will see the college president's office housed in the library. Babson also dismantled its supplemental reference collection as part of this project, removing older census and statistical publications (ABLD, 2019, pp. 5-6). The University of Chicago joined the Big Ten Academic Alliance Shared Print Repository and withdrew journals from major publishers where there was perpetual online access. Chicago will now rely on one shared copy when researchers need to see something in print (ABLD, 2019, p. 17).

\section{Other Issues Affecting Libraries}

Budgetary pressures are familiar to anyone working in libraries. Five members reported flat budgets, five reported cuts and five mentioned budget as a major influence in their reports. Fluctuating exchange rates added to the pressure at UBC and HEC Montreal (ABLD, 2019, p. 12, 36). An indirect budget pressure at UC Berkeley is the high cost of housing in the San Francisco Bay Area. It has been difficult for Berkeley to recruit and retain younger librarians (ABLD, 2019, p. 78).

\section{Evolving Libraries}

Evolution is a process that involves many minor changes that add to larger changes over time.

Sharing experiences can help other libraries paint a picture of the bigger world, allowing individual libraries to see their place in the picture as well as adapting ideas used by others to further advance their individual services. 
Ticker: The Academic Business Librarianship Review, 4:2 (2020)

http://doi.org/10.3998/ticker.16481003.0004.202

(C)2020 Greg Fleming and Carol Doyle

\section{References}

Academic Business Library Directors. (2019). Year in Review Reports 2018-2019. Unpublished report. 